\title{
Identification of Dysregulated Expression of G Protein Coupled Receptors in Endocrine Tumors by Bioinformatics Analysis: Potential Drug Targets?
}

\author{
Valentine Suteau ${ }^{1,2, *}++^{\mathbb{D}}$, Mathilde Munier ${ }^{1,2,3,+} \mathbb{D}, \operatorname{Rym}$ Ben Boubaker ${ }^{2} \mathbb{D}$, Méline Wery ${ }^{4}$, Daniel Henrion ${ }^{2} \mathbb{D}$, \\ Patrice Rodien ${ }^{1,2,3,5}$ and Claire Briet $1,2,3,5$
}

1 Département d'Endocrinologie-Diabétologie Nutrition, Centre Hospitalier Universitaire (CHU) d'Angers, 49933 Angers, France; mathilde.munier@univ-angers.fr (M.M.); parodien@chu-angers.fr (P.R.); claire.briet@chu-angers.fr (C.B.)

2 Laboratoire MITOVASC, UMR CNRS 6015, INSERM 1083, Université d'Angers, 49100 Angers, France; rym.benboubaker@univ-angers.fr (R.B.B.); daniel.henrion@univ-angers.fr (D.H.)

3 Centre de Référence des Maladies Rares de la Thyroïde et des Récepteurs Hormonaux, Centre Hospitalier Universitaire (CHU) d'Angers, 49933 Angers, France

4 Faculté de Santé, Université d'Angers, SFR ICAT, 49100 Angers, France; meline.wery@univ-angers.fr

5 Centre de Référence des Maladies Rares de l'Hypophyse, Centre Hospitalier Universitaire (CHU) d'Angers, 49933 Angers, France

* Correspondence: valentine.suteau@chu-angers.fr

+ These authors contributed equally to this work.

check for

updates

Citation: Suteau, V.; Munier, M.; Ben Boubaker, R.; Wery, M.; Henrion, D.; Rodien, P.; Briet, C. Identification of Dysregulated Expression of G Protein Coupled Receptors in Endocrine Tumors by Bioinformatics Analysis: Potential Drug Targets? Cells 2022, 11, 703. https://doi.org/10.3390/ cells11040703

Academic Editor: Hiroshi Miyamoto

Received: 14 January 2022

Accepted: 15 February 2022

Published: 17 February 2022

Publisher's Note: MDPI stays neutral with regard to jurisdictional claims in published maps and institutional affiliations.

Copyright: (c) 2022 by the authors. Licensee MDPI, Basel, Switzerland. This article is an open access article distributed under the terms and conditions of the Creative Commons Attribution (CC BY) license (https:// creativecommons.org/licenses/by/ $4.0 /)$.

\begin{abstract}
Background: Many studies link G protein-coupled receptors (GPCRs) to cancer. Some endocrine tumors are unresponsive to standard treatment and/or require long-term and poorly tolerated treatment. This study explored, by bioinformatics analysis, the tumoral profiling of the GPCR transcriptome to identify potential targets in these tumors aiming at drug repurposing. Methods: We explored the GPCR differentially expressed genes (DEGs) from public datasets (Gene Expression Omnibus (GEO) database and The Cancer Genome Atlas (TCGA)). The GEO datasets were available for two medullary thyroid cancers (MTCs), eighty-seven pheochromocytomas (PHEOs), sixty-one paragangliomas (PGLs), forty-seven pituitary adenomas and one-hundred-fifty adrenocortical cancers (ACCs). The TCGA dataset covered 92 ACCs. We identified GPCRs targeted by approved drugs from pharmacological databases (ChEMBL and DrugBank). Results: The profiling of dysregulated GPCRs was tumor specific. In MTC, we found 14 GPCR DEGs, including an upregulation of the dopamine receptor $(D R D 2)$ and adenosine receptor $(A D O R A 2 B)$, which were the target of many drugs. In PGL, seven GPCR genes were downregulated, including vasopressin receptor (AVPR1A) and PTH receptor $(P T H 1 R)$, which were targeted by approved drugs. In ACC, PTH1R was also downregulated in both the GEO and TCGA datasets and was the target of osteoporosis drugs. Conclusions: We highlight specific GPCR signatures across the major endocrine tumors. These data could help to identify new opportunities for drug repurposing.
\end{abstract}

Keywords: G protein-coupled receptors; endocrine tumors; paraganglioma; pheochromocytoma; adrenocortical cancer; medullary thyroid cancer; pituitary adenoma; drug repurposing

\section{Introduction}

G protein-coupled receptors (GPCRs) are the largest family of membrane receptors involved in many types of cellular responses. The GPCR family represents approximately $4 \%$ of the human genes, with more than 800 members [1]. GPCRs are involved in important functions, such as cardiac function, hormone regulation, immune responses and neurotransmission. Abnormal expression or activity is associated with several human diseases [2]. As a result, GPCRs are considered as therapeutic targets in many diseases. Drugs that target GPCRs account for about $34 \%$ of the current medicines, making it the 
largest family of validated pharmacological targets [3], with cumulative sales for 2011 to 2015 of $\$ 890$ billion in the United States [4]. The pharmacological targeting of GPCRs is a well-established approach for treatment in many human diseases.

Recent evidence supports the involvement of many GPCRs and their ligands in controlling the initiation and progression of tumors (cell proliferation, metastasis, adhesion or angiogenesis) [5-7]. Recently, many studies revealed that GPCRs are mutated and/or their expression dysregulated in multiple cancers [5,8]. Therefore, GPCRs can be considered as attractive targets for novel therapeutic treatments of tumors or for the repurposing of approved drugs with a target-based approach.

Bioinformatics approaches have allowed for the identification of potential therapeutic and/or prognostic targets in cancer. The Gene Expression Omnibus (GEO) and The Cancer Genome Atlas (TCGA) databases are the most frequently used to identify differentially expressed genes (DEGs). GEO is a database repository of microarrays gene expression data. The Cancer Genome Atlas (TCGA) is a project that has generated publicly available genomic and clinical data for various types of cancer [9]. GPCRomic studies have been conducted for the most frequent cancers, such as prostate or breast cancer $[7,10,11]$. In addition, the team of P. Insel focused more specifically on pancreatic adenocarcinoma [10,12,13]. Moreover, we recently established an atlas of GPCRs in radioactive iodine-resistant thyroid cancer by compiling data from the GEO database, TCGA cohort and our transcriptomic analysis [14]. However, the dysregulation of GPCR expression has not been investigated in depth in other endocrine tumors.

Endocrine tumors include tumors in glands that produce hormones (thyroid, parathyroid, pituitary, adrenal gland) and those originated from neuroendocrine cells. Medullary thyroid cancer (MTC) is a neuroendocrine tumor and arises from parafollicular cells or $\mathrm{C}$ cells. For patients with progressive and multi-metastatic MTC, the first-line systemic treatment is represented by multiple tyrosine kinase inhibitors (cabozantinib, vandetanib). These treatments have shown transient and/or partial efficacy with numerous side effects. However, there is a lack of evidence for the use of other therapies, such as chemotherapy or metabolic radiotherapy. Pituitary neuroendocrine tumors (PitNETs), traditionally designated as pituitary adenomas, include different groups of neoplasms of anterior pituitary cell origin [15]. They are classified according to the expression pattern of anterior pituitary hormones, the hormone hypersecretion and the tumor mass [16]. PitNETs are mostly well controlled after surgery. However, these tumors may exhibit aggressive behavior, with resistance to conventional treatments. The current chemotherapy, temozolomide, is effective in only one-third of the patients [17]. The same is true for primary malignant adrenal tumors, including pheochromocytoma (PHEO) and adrenocortical cancer (ACC). Pheochromocytomas (PHEOs) are tumors derived from the neural crest in the adrenal medulla. They are grouped with paragangliomas (PGLs), which share the same histological origin but are located in the paraganglia of the autonomic nervous system. The management of metastatic PHEO and PGL remains a major challenge since, to date, even though they represent less than $25 \%$ of cases, there are no curative treatment options [18]. For advanced ACC, besides surgical resection and loco-regional treatments, treatment with mitotane combined with chemotherapy (etoposide, doxorubicin and cisplatin) is often proposed according to prognostic parameters [19]. This treatment is both limited by systemic toxicity and by transient or partial efficacy.

These neuroendocrine tumors (NETs) share some features, such as slow growth and poor response to standard chemotherapies. To date, the somatostatine/somatostatine receptor (SSTR) is the only hormone-GPCR with an approved indication in the treatment of NETs. The identification of new therapeutic targets is required. We, therefore, used a GPCRomic approach to identify differentially expressed GPCRs genes in several endocrine tumors in order to identify GPCRs that may be new therapeutic targets for drug repurposing. 


\section{Materials and Methods}

\subsection{Collection of GEO Datasets and TCGA Data}

To comprehensively evaluate GPCRs expression between endocrine tumors and nontumoral tissues, we incorporated the expression data of GPCRs from GEO. We selected four types of endocrine tumors: medullary thyroid cancer (MTC), pituitary neuroendocrine tumors (PitNETs), pheochromocytoma (PHEO) and paraganglioma (PGL) and adrenocortical carcinoma (ACC). An electronic search of the GEO databases was carried out with the following key terms: "medullary thyroid", "adrenocortical", "pituitary" "pheochromocytoma", "paraganglioma", AND "cancer OR carcinoma OR tumor". The GEO datasets published before 1 April 2020 were included. We filtered data by 'Expression profiling by array' in 'homo sapiens'. The reference lists were manually reviewed for further identification of relevant studies. We selected the studies with the following inclusion criteria: studies contained mRNA expression data in tumoral and non-tumoral tissues in previous cited endocrine tumor. The exclusion criteria were: cell lines, xenograft studies, miRNA analyses, no comparison with normal tissue, duplicate. The microarray datasets were downloaded from the GEO database for each endocrine tumor and are summarized in Table 1.

To validate transcriptomic analysis, we also obtained the GPCRs expression profile of human ACC from The Cancer Genome Atlas (TCGA, https:/ / cancergenome.nih.gov/, accessed on 17 December 2021) and adrenal normal tissues from The Genotype-Tissue Expression Database (GTEX, https://gtexportal.org/home/, accessed on 17 December 2021) with online analysis tool (https:/ / insellab.github.io/, accessed on 17 December 2021). Data for other endocrine tumors were not available. 
Table 1. Gene Expression Datasets from GEO Database.

\begin{tabular}{|c|c|c|c|c|}
\hline Tumor Type & Series & Contributors & Samples & Platforms \\
\hline Medullary Thyroid Cancer & GSE27155 & Giordano TJ $[20,21]$ & 2 MTC vs. 4 normal & GPL96: Affymetrix Human Genome U133A Array \\
\hline \multirow{5}{*}{ Pituitary Neuroendocrine Tumor } & GSE36314 & Oyesiku NM [22] & 4 PitNET vs. 3 normal & GPL8300: Affymetrix Human Genome U95 Version 2 Array \\
\hline & GSE119063 & Wu Z (unpublished) & 5 PitNET vs. 4 normal & GPL13607: Agilent-028004 SurePrint G3 Human GE $8 \times 60$ K Microarray \\
\hline & GSE51618 & Feng J (unpublished) & 8 PitNET vs. 3 normal & GPL6480: Agilent-014850 Whole Human Genome Microarray $4 \times 44 \mathrm{~K}$ G4112F \\
\hline & GSE26966 & Donsom AM [23] & 14 PitNET vs. 9 normal & GPL570: Affymetrix Human Genome U133 Plus 2.0 Array \\
\hline & GSE63357 & Barry S [24-26] & 16 PitNET vs. 5 normal & GPL570: Affymetrix Human Genome U133 Plus 2.0 Array \\
\hline \multirow{4}{*}{ Pheochromocytoma } & GSE50442 & Shankavaram U (unpublished) & 3 PHEO vs. 8 normal & GPL6244: Affymetrix Human Gene 1.0 ST Array \\
\hline & GSE39716 & Shankavaram U [27-29] & 21 PHEO vs. 8 normal & GPL6244: Affymetrix Human Gene 1.0 ST Array \\
\hline & GSE19422 & López-Jiménez E [30] & 61 PHEO vs. 6 normal & GPL6480: Agilent-014850 Whole Human Genome Microarray $4 \times 44 \mathrm{~K}$ G4112F \\
\hline & GSE60459 & Choi Y-L (unpublished) & 2 PHEO vs. 3 normal & GPL13607: Agilent-028004 SurePrint G3 Human GE 8x60K Microarray \\
\hline \multirow{8}{*}{ Paraganglioma } & GSE50442 & Shankavaram U (unpublished) & 4 PGL vs. 8 normal & GPL6244: Affymetrix Human Gene 1.0 ST Array \\
\hline & GSE39716 & Shankavaram U [27-29] & 24 PGL vs. 8 normal & GPL6244: Affymetrix Human Gene 1.0 ST Array \\
\hline & GSE19422 & López-Jiménez E [30] & 23 PGL vs. 6 normal & GPL6480: Agilent-014850 Whole Human Genome Microarray $4 \times 44 \mathrm{~K}$ G4112F \\
\hline & GSE60459 & Choi Y-L (unpublished) & 10 PGL vs. 3 normal & GPL13607: Agilent-028004 SurePrint G3 Human GE 8x60K Microarray \\
\hline & GSE14922 & Szabó PM [31] & 4 ACC vs. 4 normal & GPL6480: Agilent-014850 Whole Human Genome Microarray $4 \times 44 \mathrm{~K}$ G4112F \\
\hline & GSE12368 & Soon PS [32] & 12 ACC vs. 6 normal & GPL570: Affymetrix Human Genome U133 Plus 2.0 Array \\
\hline & GSE19750 & Bussey KJ $[33,34]$ & 44 ACC vs. 4 normal & GPL570: Affymetrix Human Genome U133 Plus 2.0 Array \\
\hline & GSE33371 & Heanton JH [35] & 33 ACC vs. 10 normal & GPL570: Affymetrix Human Genome U133 Plus 2.0 Array \\
\hline
\end{tabular}

Abbreviations: Medullary thyroid cancer (MTC), Pheochromocytoma (PHEO), Paraganglioma (PGL), Pituitary neuroendocrine tumor (PitNET), Adrenocortical carcinoma (ACC). 


\subsection{Identification of Differentially Expressed Genes}

DEGs between tumoral and normal samples were identified using the GEO2R web application (http: / / www-ncbi-nlm-nih-gov.proxy.insermbiblio.inist.fr/geo/geo2r/, accessed on 7 January 2022). GEO2R is an interactive online tool, which compares two groups of samples (i.e., normal vs. tumoral) to obtain genes with different expressions under the same experimental conditions. It uses Bioconductor R packages to transform and analyze GEO data with GEO query and limma analyses [36]. We applied adjustment to the P-values with the Benjamini \& Hochberg method (false discovery rate, FDR) and a $\log _{2}$ transformation to the data. We saved the NCBI annotations where possible. Then, we filtered, from the set of genes studied, a list of 396 GPCRs (Table S1). The DEGs with an adjusted $p<0.05$ were considered as the cut-off criteria. Then, to strengthen the significance of the data, we chose to select DEGs obtained from all independent datasets of tumor tissue samples rather than combine the GSE data, as in previous publications [11,37]. We applied for Venn software online (http: / / www.interactivenn.net/, accessed on 26 June 2020) to obtain the common DEGs in all independent cohorts for each endocrine tumor [38].

\subsection{Identification of GPCRs as Targets for Approved Drugs}

We evaluated drug targets among GPCRs differentially expressed between normal and tumoral samples and the list of approved drugs for each of these receptors. This was conducted using two pharmacological databases: ChEMBL and DrugBank. DrugBank is a clinically oriented drug database that provides information about drug and drug action for more than 500,000 drugs [39]. ChEMBL is an open database containing information extracted from the medicinal chemistry literature regarding the compounds tested and their primary target [40]. Approved drugs were verified with those listed by the Food and Drug Administration (FDA) (https: / / www.fda.gov, accessed on 3 January 2022) and by the European Medicines Agency (EMA) (https://www.ema.europa.eu, accessed on 3 January 2022).

\subsection{Survival Analysis}

The GEPIA database (http:/ / gepia.cancer-pku.cn, accessed on 14 February 2022) was used for survival analysis of the dysregulated GPCR genes. Data from TCGA-ACC project (88 patients with ACC) were analyzed. To analyze the prognostic value of GPCR genes, the patient samples were split into 2 groups according to the median expression of the biomarker. The two patient cohorts were compared by a Kaplan-Meier survival plot, and the logrank P value was calculated.

\section{Results}

\subsection{Medullary Thyroid Cancer}

For medullary thyroid cancer (MTC), only one study was available from the GEO database (GSE27155). The samples consisted of four normal thyroid tissues and two medullary carcinomas. The analysis revealed 14 DEGs for GPCRs (seven downregulated and seven upregulated) (Table 2). The TSH receptor (TSHR) was the main receptor downregulated in MTC compared to normal thyroid tissue $\left(\log _{2} \mathrm{FC}:-2.22\right)$ as well as GPRC5A; an orphan receptor was also found to be downregulated $\left(\log _{2} \mathrm{FC}:-1.93\right)$. For the upregulated GPCRs, the majority were weakly upregulated, such as dopamine receptor $\left(D R D 2, \log _{2} \mathrm{FC}\right.$ : $0.62)$ and cholecystokinin receptor $\left(C C K B R, \log _{2} \mathrm{FC}: 0.59\right)$. The two most upregulated GCPRs compared to normal thyroid tissue were the adhesion receptor $A D G R G 2\left(\log _{2} \mathrm{FC}\right.$ : 1.42) and the receptor LGR5 (Leucine Rich Repeat Containing G Protein-Coupled Receptor $5, \log _{2} \mathrm{FC}: 1.43$ ). 
Table 2. List of DEGs Selected from Analysis of Medullary Thyroid Cancer Datasets.

\begin{tabular}{ccc}
\hline GPCR Gene Symbol & $\mathbf{L o g}_{\mathbf{2}} \mathbf{F C}$ & Adj- $\boldsymbol{p}$-Val \\
\hline TSHR & -2.22 & 0.0001 \\
GPRC5A & -1.93 & 0.0002 \\
OPN3 & -0.98 & 0.0011 \\
FZD1 & -0.89 & 0.0005 \\
ADGRE5 & -0.84 & 0.0014 \\
F2RL1 & -0.67 & 0.0043 \\
FZD2 & -0.56 & 0.0041 \\
CCKBR & 0.59 & 0.0025 \\
DRD2 & 0.62 & 0.0030 \\
ADORA2B & 0.64 & 0.0029 \\
CELSR3 & 0.80 & 0.0032 \\
GPR19 & 0.84 & 0.0021 \\
ADGRG2 & 1.42 & 0.0049 \\
LGR5 & 1.43 & 0.0003 \\
\hline
\end{tabular}

\subsection{Pituitary Neuroendocrine Tumors (PitNETs)}

For PitNETs, five gene expression profiles (GSE119063, GSE51618, GSE36314, GSE63357, GSE36966) were acquired from the GEO database. The dataset contained from four to sixteen tumor samples and from three to nine normal samples. The datasets consisted of several pathological subtypes of PitNETs (prolactinoma, non-functioning or GH adenoma). To be more representative, a specific pathological type was not selected. The analysis of these datasets revealed from one to sixty-six DEGs (Figure 1, Table S2). Among them, the Frizzled 7 receptor FZD7 was downregulated in the five datasets (GSE119063, $\log _{2} \mathrm{FC}=-4.26, p=0.004, \mathrm{GSE} 51618, \log _{2} \mathrm{FC}=-3.7, p=0.029, \mathrm{GSE} 36314, \log _{2} \mathrm{FC}=-0.88$, $p=0.034$, GSE63357, $\log _{2} \mathrm{FC}=-0.70, p=0.009, \mathrm{GSE} 36966, \log _{2} \mathrm{FC}=-3.57, p<0.001$ ). Interestingly, in the GSE51618 dataset, we could also compare the expression profile between invasive and non-invasive nonfunctional pituitary adenomas. SSTR1 was highly upregulated in invasive adenoma $\left(\log _{2} \mathrm{FC}=9.14, p=0.005\right)$ as well as the adhesion receptor ADGRG2 $\left(\log _{2} \mathrm{FC}=5.26, p=0.026\right)$, the serotonin receptor HTR4 $5\left(\log _{2} \mathrm{FC}=3.68, p=0.007\right)$ and the prostaglandin receptor PTGER2 $\left(\log _{2} \mathrm{FC}=3.06, p=0.038\right)$. Conversely, adhesion receptors $A D G R A 1$ and $A D G R L 3$ were downregulated in invasive tumors $\left(\log _{2} \mathrm{FC}=-3.41\right.$, $p=0.040, \log _{2} \mathrm{FC}=-5.66, p=0.042$, respectively) (Figure 1 ). 

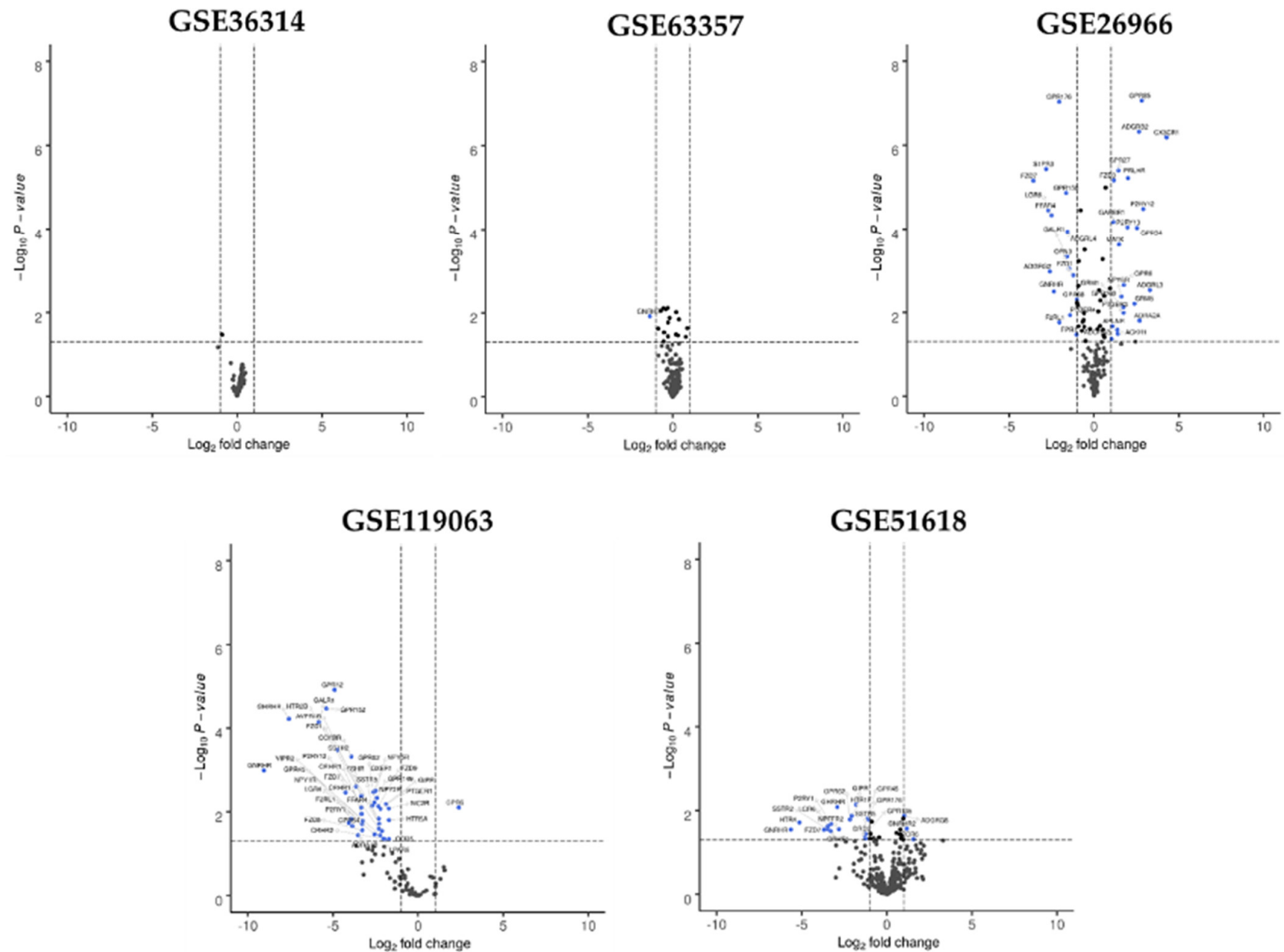

(A)

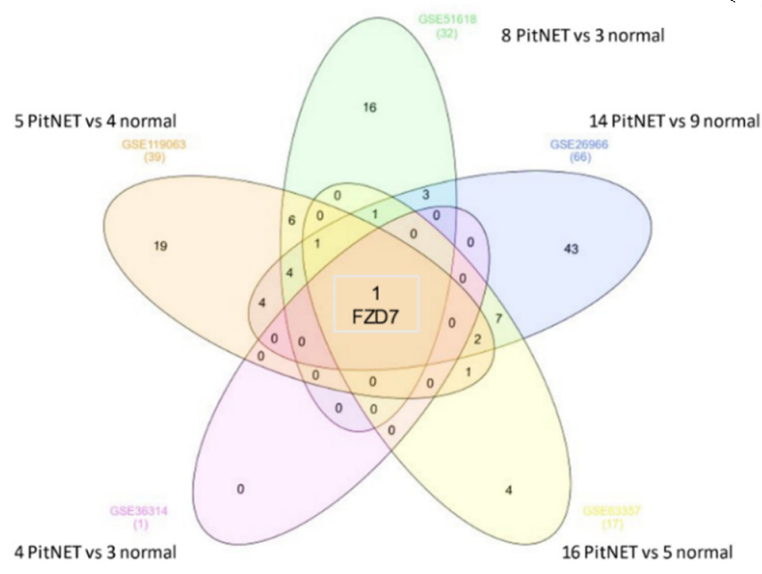

(B)

\begin{tabular}{ccc}
\hline GPCR Gene & Log $^{2} \mathbf{F C}$ & adj- $p$-Val \\
\hline ADGRL3 & -5.66 & 0.042 \\
ADGRA1 & -3.41 & 0.040 \\
ADCYAP1R1 & -2.51 & 0.003 \\
FFAR2 & 1.27 & 0.042 \\
C5AR1 & 1.44 & 0.037 \\
CXCR5 & 1.85 & 0.029 \\
PTGER2 & 3.06 & 0.038 \\
HTR4 & 3.68 & 0.007 \\
ADGRG2 & 5.26 & 0.026 \\
SSTR1 & 9.14 & 0.005 \\
\hline
\end{tabular}

(C)

Figure 1. Dysregulated GPCR in pituitary neuroendocrine tumors. (A) Volcano plots for GSE119063, GSE51618, GSE26966, GSE63357 and GSE36314. Each GPCR transcript was represented by a spot. $\log _{2}$ fold change was plotted against the $-\log _{10} p$-value $(<0.05$, horizontal line). Differentially expressed GPCR genes were selected with adjusted $p<0.05$ among the mRNA expression profiling datasets; (B) Venn diagram for GSE119063, GSE51618, GSE26966, GSE63357 and GSE36314 datasets. For each dataset, the number of significant DEGs was indicated in brackets. One GPCR gene (FZD7) was identified in the five datasets; (C) list of DEGs selected from analysis of invasive vs. noninvasive PitNETs in GSE51618 datasets. Abbreviation: PitNETs (pituitary neuroendocrine tumors), FC, fold-change. 


\subsection{Pheochromocytoma and Paraganglioma}

Four gene expression profiles (GSE50442, GSE39716, GSE19422, GSE60459) were acquired from the GEO database for pheochromocytoma and paraganglioma. The dataset contained from two to sixty-one pheochromocytoma samples, four to twenty-four paraganglioma and from three to eight normal samples (medullar adrenal tissue). All PHEOs were non-metastatic. For PGL, GSE39716 and GSE60459 included ten and three metastatic paraganglioma, respectively.

The data for PHEO were quite heterogeneous among the four studies. The number of GPCRs with a significant difference in expression between healthy and tumor tissue varied between 12 and 86 (Figure 2, Table S3). Although there was no receptor significantly common to all four series, the angiotensin II type 2 receptor (AGTR2) was found to be downregulated in the tumor tissue in all the studies (GSE60459, $\log _{2} \mathrm{FC}=-1.1, p=0.03$; GSE50442, $\log _{2} \mathrm{FC}=-0.56, p=0.493$; GSE39716, $\log _{2} \mathrm{FC}=-0.75, p=0.003 ;$ GSE19422, $\left.\log _{2} \mathrm{FC}=-0.60, p=0.003\right)$.

In PGL, the analysis revealed from 37 to 69 DEGs for GPCRs. Venn diagram analysis revealed that seven GPCRs were down regulated compared with normal adrenal gland in the four datasets (AVPR1A, MC2R, NPY5R, NPY6R, RXFP1, LGR4, PTH1R) (Figure 3, Table S4). When we compared metastatic PGL and non-metastatic PGL in GSE39716 and GSE60459, no significant DEG were found.
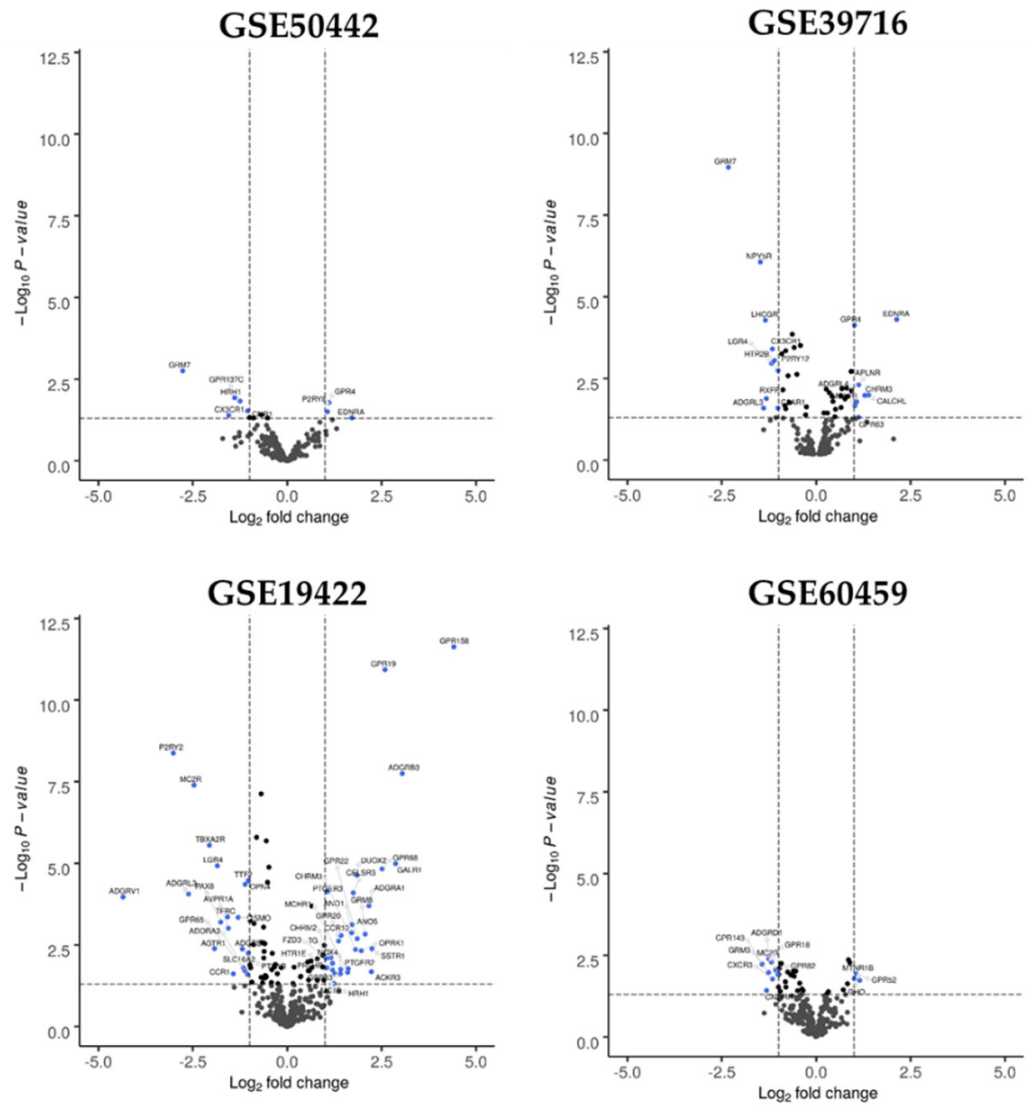

(A)

Figure 2. Cont. 


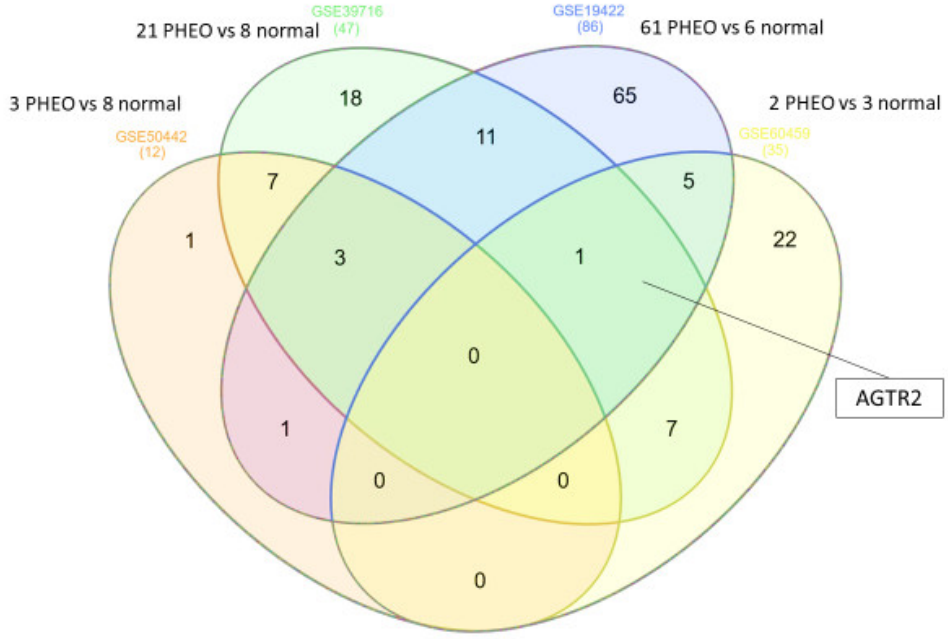

(B)

Figure 2. Dysregulated GPCR in pheochromocytoma. (A) Volcano plots for GSE50442, GSE39716, GSE19422, GSE60459. Each GPCR transcript was represented by a spot. $\log _{2}$ fold change was plotted against the $-\log _{10} p$-value $(p<0.05$, horizontal line). Differentially expressed GPCR genes were selected with adjusted $p<0.05$ among the mRNA expression profiling datasets; (B) Venn diagram for GSE50442, GSE39716, GSE19422, GSE60459 datasets. For each dataset, the number of significant DEGs was indicated in brackets. Abbreviation: FC, fold-change.
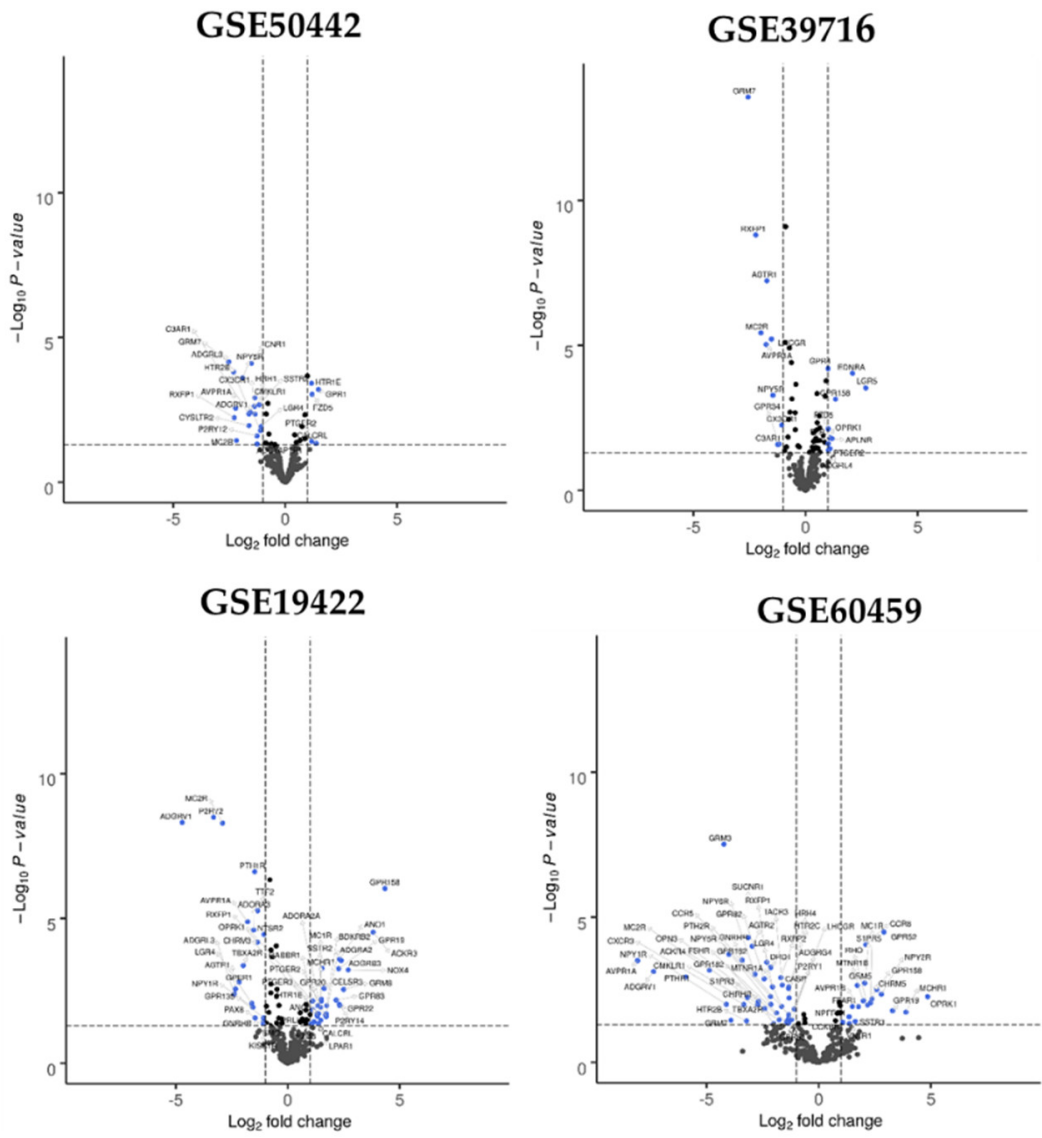

(A)

Figure 3. Cont. 


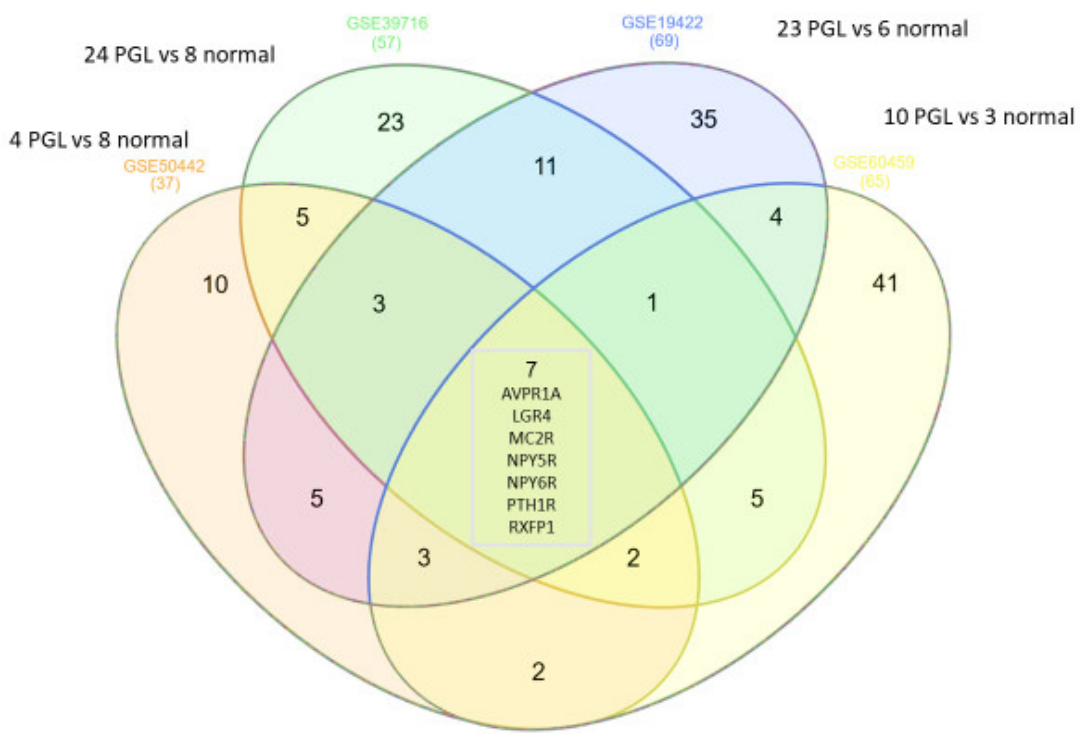

(B)

Figure 3. Dysregulated GPCR in paraganglioma. (A) Volcano plots for GSE50442, GSE39716, GSE19422, GSE60459. Each GPCR transcript was represented by a spot. $\log _{2}$ fold change was plotted against the $-\log 10 p$-value $(p<0.05$, horizontal line). Differentially expressed GPCR genes were selected with adjusted $p<0.05$ among the mRNA expression profiling datasets; (B) Venn diagram for GSE50442, GSE39716, GSE19422, GSE60459 datasets. For each dataset, the number of significant DEGs was indicated in brackets. Seven GPCR genes were identified in the four datasets. Abbreviation: PGL: paraganglioma, FC, fold-change.

\subsection{Adrenocortical Carcinomas}

For ACC, five gene expression profiles (GSE14922, GSE90713, GSE12368, GSE19750, GSE33371) were acquired from the GEO database. The dataset contained from four to fiftyseven cancer samples and from four to ten normal samples. The analysis of these datasets revealed six, eight, fifteen, nine and fifty-two DEGs, respectively. Venn diagram analysis revealed that PTH1R was the only gene downregulated in the five datasets (Figure 4, Table S5). To validate this finding, TCGA data (TCGA-ACC Project) were used to quantify differential expression of PTH1R by comparing tumors against adrenal normal tissue from the Gene Tissue Expression Project (GTEx) database. In the TCGA cohort, PTH1R was also downregulated $\left(\log _{2} \mathrm{FC}:-3.37, p<0.0001\right)$.

\subsection{Identification of Dysregulated G Protein Coupled Receptors as Targets for Approved Drugs}

Among the dysregulated GPCR, we determined which receptors were targeted by approved drugs and how many drugs were available for these targets. The data were summarized in the Table 3. In MTC, among the $14 \mathrm{DEG}, C C K B R, D 2 R$ and Adenosine A2B receptor $(A D O R A 2 B)$ were the target of drugs. $D R D 2$ was the most frequently targeted receptor with over 40 anti-psychotic agents acting as $D R D 2$ antagonists. For PitNET, any drug did not target FZD7. Interestingly, three up-regulated GPCR in invasive PitNET were targeted receptor: SSTR1, HTR4 and PTGER2. Among the seven down-regulated GPCRs in paraganglioma, Arginine Vasopressin Receptor 1A (AVPR1A), ACTH receptor, $M C 2 R$, and PTH1R were the target of 2 to 4 drugs each. PTH1R also found to be downregulated in adrenocortical cancer, was targeted by 3 agonists used in osteoporosis or hypoparathyroidism. 

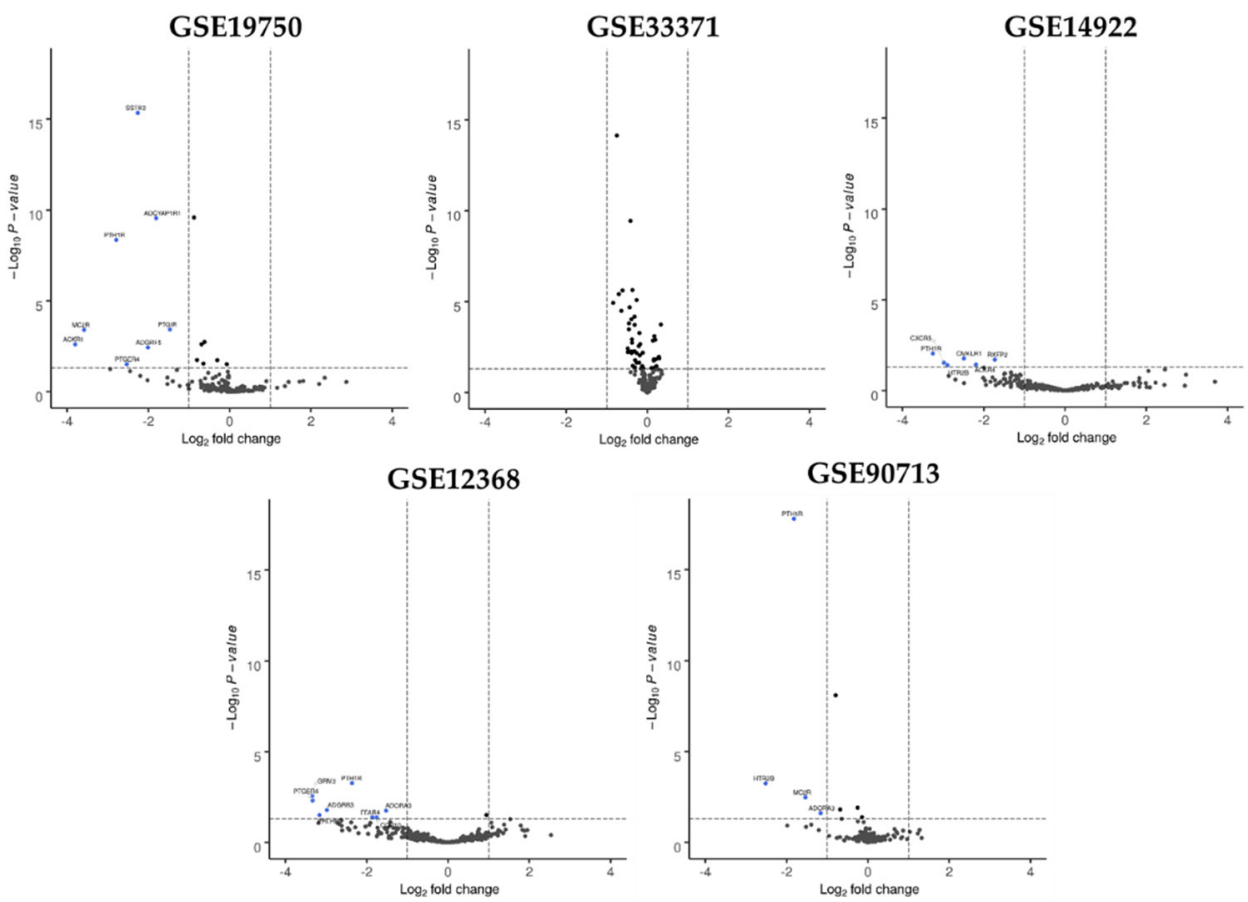

(A)

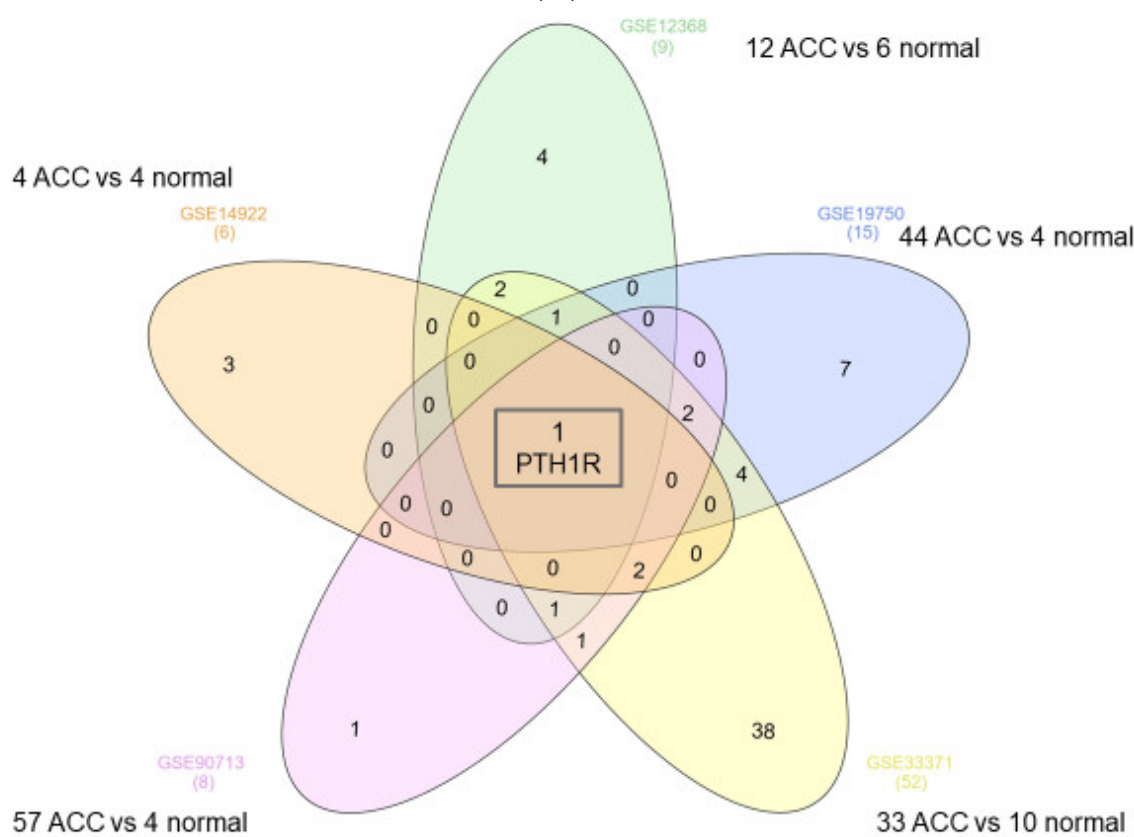

(B)

Figure 4. Dysregulated GPCR in adrenocortical cancer. (A) Volcano plots for GSE14922, GSE12368, GSE19750, GSE33371, GSE90713. Each GPCR transcript was represented by a spotLog 2 fold change plotted against the $-\log 10 p$-value ( $p<0.05$, horizontal line). Differentially expressed GPCR genes were selected with adjusted $p<0.05$. Differentially expressed GPCR genes were selected with adjusted $p<0.05$ among the mRNA expression profiling datasets; (B) Venn diagram for GSE14922, GSE12368, GSE19750, GSE33371, GSE90713 datasets. For each dataset, the number of significant DEGs was indicated in brackets. One GPCR gene (PTH1R) was identified in the five datasets. Abbreviation: FC, fold-change. 
Table 3. List of GPCRs with Approved Drugs.

\begin{tabular}{|c|c|c|}
\hline GPCR & Mode of Action & Main Indication(s) \\
\hline \multicolumn{3}{|l|}{ ADORA2B } \\
\hline Caffeine & Antagonist & pulmonary complications of premature birth \\
\hline Enprofylline & Antagonist & Asthma \\
\hline Theophylline & Antagonist & Asthma \\
\hline Adenosine & Agonist & supraventricular tachycardia \\
\hline AVPR1A & & \\
\hline Atosiban & Antagonist & pre-term labour \\
\hline Conivaptan & Antagonist & SIADH \\
\hline Felypressin & Agonist & diabetes insipidus \\
\hline $\begin{array}{l}\text { Terlipressin } \\
\text { CCKBR }\end{array}$ & Agonist & bleeding caused by esophageal varices. \\
\hline $\begin{array}{l}\text { Pentagastrin } \\
\text { DRD2 }\end{array}$ & Agonist & evaluation of gastric acid secretory function \\
\hline$>40$ Drugs & Antagonist & antipsychotic agent \\
\hline Alizapride & Antagonist & anti-emetic \\
\hline Bromopride & Antagonist & anti-emetic \\
\hline Domperidone & Antagonist & anti-emetic \\
\hline Droperidol & Antagonist & anti-emetic \\
\hline Metoclopramide & Antagonist & anti-emetic \\
\hline 8 Drugs * & Agonist & Parkinson's disease \\
\hline Cabergoline & Agonist & pituitary adenoma \\
\hline $\begin{array}{l}\text { Quinagolide } \\
\text { HTR4 }\end{array}$ & Agonist & pituitary adenoma \\
\hline Vilazodone & Agonist & Depressive disorder \\
\hline Mosapride & Agonist & Gastroprokinetic agent \\
\hline Cisapride & Agonist & Gastroprokinetic agent \\
\hline Prucalopride & Agonist & Gastroprokinetic agent \\
\hline Cinitapride & Agonist & Gastroprokinetic agent \\
\hline Tegaserod & Agonist & Gastroprokinetic agent \\
\hline $\begin{array}{c}\text { Metoclopramide } \\
\text { MC2R }\end{array}$ & Antagonist & anti-emetic \\
\hline Corticotropin & Agonist & diagnosis agent \\
\hline $\begin{array}{l}\text { Tetracosactide } \\
\text { PTGER2 }\end{array}$ & Agonist & diagnosis agent \\
\hline Alprostadil & Agonist & erectile dysfunction \\
\hline Dinoprostone & Agonist & labor induction \\
\hline Misoprostol & Agonist & gastric ulcer \\
\hline Gemeprost & Agonist & pregnancy termination \\
\hline $\begin{array}{l}\text { Limaprost } \\
\text { PTH1R }\end{array}$ & Agonist & Ischemic ulcer \\
\hline Abaloparatide & Agonist & Osteoporosis \\
\hline Parathyroid hormone & Agonist & Hypoparathyroidism \\
\hline $\begin{array}{l}\text { Teriparatide } \\
\text { SSTR1 }\end{array}$ & Agonist & Osteoporosis \\
\hline Octreotide & Agonist & NeuroEndocrine tumor \\
\hline Pasireotide & Agonist & NeuroEndocrine tumors \\
\hline
\end{tabular}

For each endocrine tumor, common dysregulated GPCR were reviewed and approved drugs were listed with their mode of action and their main indications. Abbreviations: SIADH $=$ Syndrome of inappropriate antidiuretic hormone secretion. *: The eight DRD2 agonist were: Amantadine, apomorphine, Levodopa, lisuride, pergolide, pramipexole, ropinirole, rotigotine.

\subsection{Survival Analysis}

Survival data were only available for ACC from TCGA. We, therefore, chose to study the gene expression of PTH1R for ACC. Using the GEPIA database to explore the association between gene expression and survival, we found that PTH1R expression was neither significantly correlated with overall survival nor disease-free survival of ACC patients $(\log$-rank $p=0.72$ and $\log$-rank $p=0.88$, respectively) (Figure 5). 


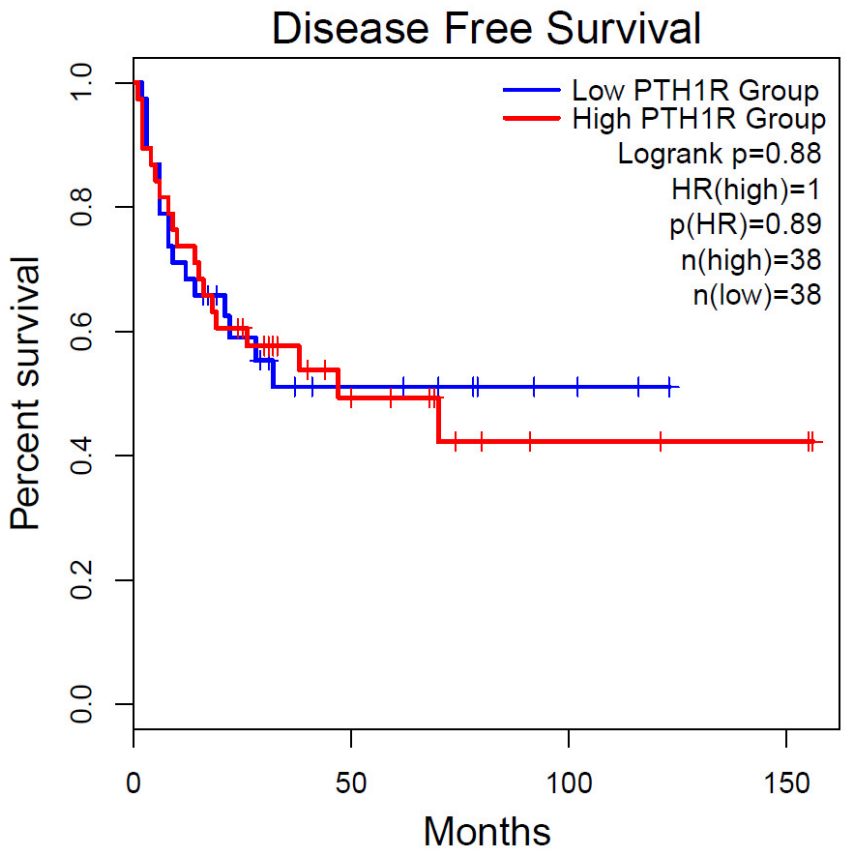

(A)

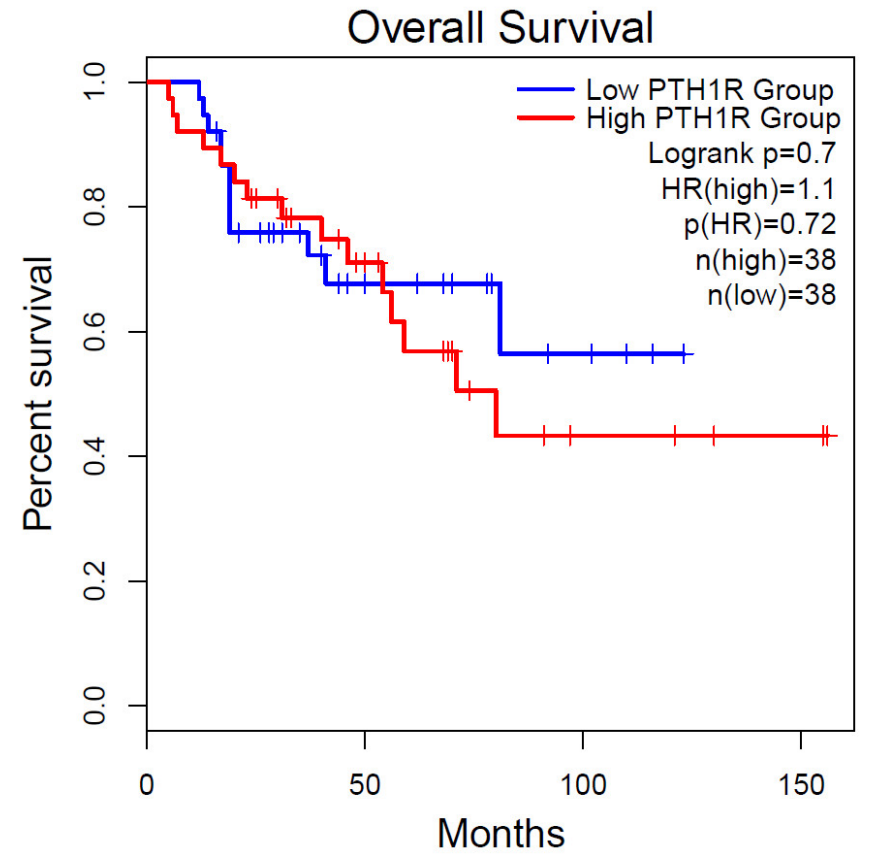

(B)

Figure 5. Survival analysis for $P T H 1 R$ in adrenocortical cancer. To analyze the prognostic value of PTH1R gene expression, the patient samples are split into 2 groups according to the median expressions of the genes. The 2 patient cohorts were compared by a Kaplan-Meier survival plot, and $\log$-rank $p$ value was calculated. (A) Disease free survival; (B) overall survival.

\section{Discussion}

This study constitutes the first atlas of GPCRs within major endocrine tumors after thyroid cancer [14]. Drug repurposing strategies provided a new approach for revealing new clinical applications of an approved drug and for developing antitumor drugs. The use of GPCRomic approaches leads to the discovery of GPCRs that could contribute to cancer pathophysiology and, thus, may be therapeutic targets.

\subsection{Medullary Thyroid Cancer}

We confirmed the upregulation of cholecystokinin 2 receptor (CCKBR/CCK2R) expression in MTC, which is targeted by radiolabeled peptide analogs for molecular imaging and targeted radiotherapy of different human tumors, such as MTC [41,42]. The dopamine receptor DRD2 was also upregulated. It is known that L-dopa inhibits calcitonin secretion in MTC, and a new chimeric somatostatin-dopamine analog has recently shown an anti-tumor effect in vitro [43]. Interestingly, $D R D 2$ is the target of many drugs already approved and is, therefore, accessible for drug repurposing. Like $D R D 2$, the adenosine receptor $A D O R A 2 B$ was upregulated and the target of approved drugs. However, sparse data are available on the role of these treatments in thyroid cancer, although previous studies have shown a role for adenosine receptors in calcitonin secretion in C-cells [44]. ADGRG2/GPR64 was also over-expressed in MTC $\left(\log _{2} \mathrm{FC}=1.42, p=0.0049\right)$ as in a number of carcinomas derived from breast cancer, parathyroid tumors, Ewing sarcomas, prostate, kidney or lung, and the inhibition of its expression promotes invasiveness and metastatic spread [45,46]. GPRC5A was downregulated $\left(\log _{2} \mathrm{FC}=1.93, p=0.0002\right)$ as previously reported in other cancers, especially in lung cancer, where it displayed a tumor suppressive role [47]. FZD1 was also downregulated as previously described in non-medullary thyroid cancer, in which inhibition increased invasiveness, indicating a possible pathogenesis role [48]. However, to have only one study with a very small number of samples limits the significance of the findings for medullary thyroid cancer. In addition, the different histological origin 
between the normal tissue (mainly of follicular origin) and tumor tissue (medullary origin) probably explains part of the results. This is the case, for example, with the downregulation of the TSH receptor (TSH-R), which is strongly expressed in normal thyroid tissue but was negligible in MTC, as expected [49].

\subsection{Pituitary Neuroendocrine Tumors (PitNETs)}

Five studies were available in the GEO database comparing pituitary adenomas and the normal pituitary. Data regarding aggressiveness were not available. Independent of tumor characteristics (secreting or non-secreting, invasive or non-invasive), Frizzled receptor 7 (FZD7) was downregulated in PitNETs. Interestingly, in invasive adenomas compared to the normal pituitary gland (GSE51618) FZD7 was also found to be downregulated. To date, this data was not described before in the literature. However, SFRP2 and 4 (secreted-frizzled related protein), Wnt antagonists, considered as tumor suppressor genes, were downregulated in pituitary adenomas, in particular in invasive tumors, suggesting a role of the Wnt pathway in the progression of PitNETs [50-52]. Among the differentially expressed GPCR genes between non-invasive and invasive tumors, the somatostatin type 1 receptor (SSTR1) was known and already targeted by somatostatin analogs. HTR4 and PTGER2 were also targeted by agonists. The antitumoral and antiangiogenic effects of HTR4 agonists were thus shown $[53,54]$.

\subsection{Pheochromocytoma or Paraganglioma}

For PHEO, no receptor was significantly common to all four series. However, even if, in one study, angiotensin II type 2 receptor (AGTR2) was not statistically downregulated, it was found to be downregulated in the tumoral tissue in all the studies. Indeed, the absence or a very low expression of AGTR2 has been described in PHEO [55]. Interestingly, this receptor has been also described for its antiproliferative role in cancer, including in the pheochromocytoma PC12 cell line in response to angiotensin II [56]. However, unlike the angiotensin II type 1 receptor, no approved drug targets the AGTR2. In addition, it would be interesting to have metastatic pheochromocytomas to compare the profile between metastatic and non-metastatic, as for paragangliomas. However, no data were available.

For PGL, seven GPCRs were found to be downregulated when compared to normal medulla adrenal tissue. However, no data are available in the literature regarding their expression level or their role in paragangliomas. Interestingly, the arginine vasopressin receptor, AVPR1A, was also found to be downregulated in thyroid cancer and associated with progression-free survival, while it was upregulated in castration-resistant prostate cancer with an antitumoral effect of a selective AVPR1A antagonist [14,57]. Moreover, AVPR1A agonist and antagonists are approved drugs and could be tested as proof of concept. When we compared malignant paraganglioma and benign paraganglioma, no significant DEGs were found. The patient numbers were small in the two datasets, probably limiting the statistical power of the analyses.

\subsection{Adrenocortical Carcinoma}

In ACC, PTH1R was found downregulated in $5 / 5$ datasets. This result was confirmed in ACC samples from the TCGA cohort. PTH1R is a major endocrine regulator of skeletal development and mineral homeostasis. It was also found that PTH1R enhanced the secretion of steroid hormones by human adrenocortical cells via a signaling mechanism involving the activation of both the Gs and Gq pathways [58]. PTH1R was previously immunolocalized in the cytoplasm in a normal adrenal cortex [59]. The PTH1R mRNA expression level was significantly higher in aldosterone-producing adenomas than in cortisol-producing adenoma [59] but seemed to be similar between ACCs and adenomas [60]. To the best of our knowledge, this is the first comparison between ACCs and a normal adrenal cortex. We found a downregulation of PTH1R, while PTHrp seemed to have a positive effect on the proliferation of the H295R lineage [60]. This could be explained by a downregulation of PTH1R by PTHrP, as described in vascular smooth muscle, osteoblastic or kidney cell 
lines [61]. The role of PTH1R in tumor progression is still poorly understood. Indeed, PTH1R knockdown increased cell migration and invasion and decreased tumor differentiation in neuroblastoma but had an opposite effect in osteoblastoma [62]. Finally, the PTH1R expression was neither significantly correlated with overall survival nor disease-free survival in ACC patients. However, there were only 88 patients in the study, probably limiting the statistical power of the analyses. Moreover, the absence of an association with survival should not, in our opinion, compromise potential therapeutic targets, as in thyroid cancer, where TSH inhibition influences survival even though its receptor expression level in the tumor is not associated with overall survival $[14,63]$.

RNA-seq and microarrays that assess GPCR expression have certain limitations. First, RNA expression does not necessarily reflect protein expression. However, methods to assess GPCR protein expression are limited. Immunological techniques are limited by the lack of well-validated and specific GPCR antibodies [64]. The low expression of GPCRs compared to other proteins makes detection of GPCRs complicated. Moreover, recent studies found a closer relationship between the mRNA and protein, especially for GPCRs $[65,66]$. Another alternative to validate GPCR expression would be cell signaling and functional assays. Second, the clinical data were not associated with the microarrays data in the GEO repository, which limits the evaluation of the prognostic impact of these GPCRs on recurrence or progression. The data from the GPCRomic analyses need to be validated by further prospective studies for specific GPCRs with clinical evaluation.

\section{Conclusions}

This study presented all the data available to date regarding GPCRs in endocrine tumors. The data could help to identify new potential pathways worth targeting, eventually with approved drugs after proving the tumoral impact in preclinical models. The highthroughput screening of clinically relevant GPCRs with approved drugs would then be an interesting tool for the evaluation of these molecules in endocrine tumors.

Supplementary Materials: The following are available online at https:/ /www.mdpi.com/article/10 .3390 / cells11040703/s1, Table S1: List of GPCR genes included in bioinformatics analysis. Table S2: List of DEGs selected from analysis of pituitary adenoma datasets. Table S3: List of DEGs selected from analysis of pheochromocytoma datasets. Table S4. List of DEGs selected from analysis of paraganglioma datasets. Table S5: List of DEGs selected from analysis of adrenocortical cancer datasets.

Author Contributions: V.S.: Conceptualization, Methodology, formal analysis, investigation, data curation, writing — original draft preparation, project administration, funding acquisition; M.M.: validation, project administration, writing - review and editing, funding acquisition; R.B.B.: Graphical abstract, Software, formal analysis; M.W.: Software, formal analysis; D.H.: validation, writingreview and editing, project administration, resources, funding acquisition; P.R.: Methodology; validation, writing - review and editing, supervision, project administration, funding acquisition; C.B.: validation, Methodology, writing—review and editing, supervision, project administration, funding acquisition. All authors have read and agreed to the published version of the manuscript.

Funding: This research was funded by le Plan National Cancer-Inserm (France) and Pfizer, Endocrinology Reserach Price (France).

Institutional Review Board Statement: Not applicable.

Informed Consent Statement: Not applicable.

Data Availability Statement: The datasets generated and/or analyzed during the current study are available from the corresponding author on reasonable request.

Conflicts of Interest: The authors declare no conflict of interest. The funders had no role in the design of the study; in the collection, analyses or interpretation of data; in the writing of the manuscript or in the decision to publish the results. 


\section{References}

1. Bjarnadóttir, T.K.; Gloriam, D.E.; Hellstrand, S.H.; Kristiansson, H.; Fredriksson, R.; Schiöth, H.B. Comprehensive Repertoire and Phylogenetic Analysis of the G Protein-Coupled Receptors in Human and Mouse. Genomics 2006, 88, 263-273. [CrossRef] [PubMed]

2. Rosenbaum, D.M.; Rasmussen, S.G.F.; Kobilka, B.K. The Structure and Function of G-Protein-Coupled Receptors. Nature 2009, 459, 356-363. [CrossRef]

3. Sriram, K.; Insel, P.A. G Protein-Coupled Receptors as Targets for Approved Drugs: How Many Targets and How Many Drugs? Mol. Pharm. 2018, 93, 251-258. [CrossRef] [PubMed]

4. Hauser, A.S.; Attwood, M.M.; Rask-Andersen, M.; Schiöth, H.B.; Gloriam, D.E. Trends in GPCR Drug Discovery: New Agents, Targets and Indications. Nat. Rev. Drug Discov. 2017, 16, 829-842. [CrossRef] [PubMed]

5. Dorsam, R.T.; Gutkind, J.S. G-Protein-Coupled Receptors and Cancer. Nat. Rev. Cancer 2007, 7, 79-94. [CrossRef] [PubMed]

6. Lappano, R.; Maggiolini, M. G Protein-Coupled Receptors: Novel Targets for Drug Discovery in Cancer. Nat. Rev. Drug Discov. 2011, 10, 47-60. [CrossRef]

7. Wu, V.; Yeerna, H.; Nohata, N.; Chiou, J.; Harismendy, O.; Raimondi, F.; Inoue, A.; Russell, R.B.; Tamayo, P.; Gutkind, J.S. Illuminating the Onco-GPCRome: Novel G Protein-Coupled Receptor-Driven Oncocrine Networks and Targets for Cancer Immunotherapy. J. Biol. Chem. 2019, 294, 11062-11086. [CrossRef]

8. O'Hayre, M.; Vázquez-Prado, J.; Kufareva, I.; Stawiski, E.W.; Handel, T.M.; Seshagiri, S.; Gutkind, J.S. The Emerging Mutational Landscape of G-Proteins and G-Protein Coupled Receptors in Cancer. Nat. Rev. Cancer 2013, 13, 412. [CrossRef]

9. Cheng, P.F.; Dummer, R.; Levesque, M.P. Data Mining The Cancer Genome Atlas in the Era of Precision Cancer Medicine. Swiss Med. Wkly. 2015, 145, w14183. [CrossRef]

10. Insel, P.A.; Sriram, K.; Wiley, S.Z.; Wilderman, A.; Katakia, T.; McCann, T.; Yokouchi, H.; Zhang, L.; Corriden, R.; Liu, D.; et al GPCRomics: GPCR Expression in Cancer Cells and Tumors Identifies New, Potential Biomarkers and Therapeutic Targets. Front. Pharm. 2018, 9, 431. [CrossRef]

11. Kübler, E.; Albrecht, H. Large Set Data Mining Reveals Overexpressed GPCRs in Prostate and Breast Cancer: Potential for Active Targeting with Engineered Anti-Cancer Nanomedicines. Oncotarget 2018, 9, 24882-24897. [CrossRef] [PubMed]

12. Sriram, K.; Moyung, K.; Corriden, R.; Carter, H.; Insel, P.A. GPCRs Show Widespread Differential MRNA Expression and Frequent Mutation and Copy Number Variation in Solid Tumors. PLoS Biol. 2019, 17, e3000434. [CrossRef] [PubMed]

13. Wiley, S.Z.; Sriram, K.; Liang, W.; Chang, S.E.; French, R.; McCann, T.; Sicklick, J.; Nishihara, H.; Lowy, A.M.; Insel, P.A. GPR68, a Proton-Sensing GPCR, Mediates Interaction of Cancer-Associated Fibroblasts and Cancer Cells. FASEB J. 2018, 32, 1170-1183. [CrossRef] [PubMed]

14. Suteau, V.; Seegers, V.; Munier, M.; Ben Boubaker, R.; Reyes, C.; Gentien, D.; Wery, M.; Croué, A.; Illouz, F.; Hamy, A.; et al. G Protein-Coupled Receptors in Radioiodine-Refractory Thyroid Cancer in the Era of Precision Medicine. J. Clin. Endocrinol. Metab. 2021, 106, 2221-2232. [CrossRef]

15. Asa, S.L.; Casar-Borota, O.; Chanson, P.; Delgrange, E.; Earls, P.; Ezzat, S.; Grossman, A.; Ikeda, H.; Inoshita, N.; Karavitaki, N.; et al. From Pituitary Adenoma to Pituitary Neuroendocrine Tumor (PitNET): An International Pituitary Pathology Club Proposal. Endocr. Relat. Cancer 2017, 24, 5-8. [CrossRef]

16. Saeger, W.; Honegger, J.; Theodoropoulou, M.; Knappe, U.J.; Schöfl, C.; Petersenn, S.; Buslei, R. Clinical Impact of the Current WHO Classification of Pituitary Adenomas. Endocr. Pathol. 2016, 27, 104-114. [CrossRef]

17. Raverot, G.; Burman, P.; McCormack, A.; Heaney, A.; Petersenn, S.; Popovic, V.; Trouillas, J.; Dekkers, O.M. European Society of Endocrinology Clinical Practice Guidelines for the Management of Aggressive Pituitary Tumours and Carcinomas. Eur. J. Endocrinol. 2018, 178, 1-24. [CrossRef]

18. Fassnacht, M.; Assie, G.; Baudin, E.; Eisenhofer, G.; de la Fouchardiere, C.; Haak, H.R.; de Krijger, R.; Porpiglia, F.; Terzolo, M.; Berruti, A. Adrenocortical Carcinomas and Malignant Phaeochromocytomas: ESMO-EURACAN Clinical Practice Guidelines for Diagnosis, Treatment and Follow-Up+†Approved by the ESMO Guidelines Committee: June 2020. This Publication Supersedes the Previously Published Version-Ann Oncol. 2012;23(Suppl_7):Vii131-Vii138. Ann. Oncol. 2020, 31, 1476-1490. [CrossRef]

19. Fassnacht, M.; Dekkers, O.M.; Else, T.; Baudin, E.; Berruti, A.; de Krijger, R.R.; Haak, H.R.; Mihai, R.; Assie, G.; Terzolo, M. European Society of Endocrinology Clinical Practice Guidelines on the Management of Adrenocortical Carcinoma in Adults, in Collaboration with the European Network for the Study of Adrenal Tumors. Eur. J. Endocrinol. 2018, 179, 1-46. [CrossRef]

20. Giordano, T.J.; Kuick, R.; Thomas, D.G.; Misek, D.E.; Vinco, M.; Sanders, D.; Zhu, Z.; Ciampi, R.; Roh, M.; Shedden, K.; et al. Molecular Classification of Papillary Thyroid Carcinoma: Distinct BRAF, RAS, and RET/PTC Mutation-Specific Gene Expression Profiles Discovered by DNA Microarray Analysis. Oncogene 2005, 24, 6646-6656. [CrossRef]

21. Giordano, T.J.; Au, A.Y.M.; Kuick, R.; Thomas, D.G.; Rhodes, D.R.; Wilhelm, K.G.; Vinco, M.; Misek, D.E.; Sanders, D.; Zhu, Z.; et al. Delineation, Functional Validation, and Bioinformatic Evaluation of Gene Expression in Thyroid Follicular Carcinomas with the PAX8-PPARG Translocation. Clin. Cancer Res. 2006, 12, 1983-1993. [CrossRef] [PubMed]

22. Tong, Y.; Zheng, Y.; Zhou, J.; Oyesiku, N.M.; Koeffler, H.P.; Melmed, S. Genomic Characterization of Human and Rat Prolactinomas. Endocrinology 2012, 153, 3679-3691. [CrossRef]

23. Gump, J.M.; Donson, A.M.; Birks, D.K.; Amani, V.M.; Rao, K.K.; Griesinger, A.M.; Kleinschmidt-DeMasters, B.K.; Johnston, J.M.; Anderson, R.C.E.; Rosenfeld, A.; et al. Identification of Targets for Rational Pharmacological Therapy in Childhood Craniopharyngioma. Acta Neuropathol. Commun. 2015, 3, 1-12. [CrossRef] [PubMed] 
24. Barry, S.; Carlsen, E.; Marques, P.; Stiles, C.E.; Gadaleta, E.; Berney, D.M.; Roncaroli, F.; Chelala, C.; Solomou, A.; Herincs, M.; et al. Tumor Microenvironment Defines the Invasive Phenotype of AIP-Mutation-Positive Pituitary Tumors. Oncogene 2019, 38, 5381-5395. [CrossRef]

25. Hernández-Ramírez, L.C.; Morgan, R.M.L.; Barry, S.; D’Acquisto, F.; Prodromou, C.; Korbonits, M. Multi-Chaperone Function Modulation and Association with Cytoskeletal Proteins Are Key Features of the Function of AIP in the Pituitary Gland. Oncotarget 2018, 9, 9177-9198. [CrossRef] [PubMed]

26. Marques, P.; Barry, S.; Carlsen, E.; Collier, D.; Ronaldson, A.; Awad, S.; Dorward, N.; Grieve, J.; Mendoza, N.; Muquit, S.; et al. Chemokines Modulate the Tumour Microenvironment in Pituitary Neuroendocrine Tumours. Acta Neuropathol. Commun. 2019, 7, 1-21. [CrossRef] [PubMed]

27. Giubellino, A.; Shankavaram, U.; Bullova, P.; Schovanek, J.; Zhang, Y.; Shen, M.; Patel, N.; Elkahloun, A.; Lee, M.-J.; Trepel, J.; et al. High-Throughput Screening for the Identification of New Therapeutic Options for Metastatic Pheochromocytoma and Paraganglioma. PLoS ONE 2014, 9, e90458. [CrossRef]

28. Shankavaram, U.; Fliedner, S.M.J.; Elkahloun, A.G.; Barb, J.J.; Munson, P.J.; Huynh, T.T.; Matro, J.C.; Turkova, H.; Linehan, W.M.; Timmers, H.J.; et al. Genotype and Tumor Locus Determine Expression Profile of Pseudohypoxic Pheochromocytomas and Paragangliomas. Neoplasia 2013, 15, 435-447. [CrossRef]

29. Yang, C.; Zhuang, Z.; Fliedner, S.M.J.; Shankavaram, U.; Sun, M.G.; Bullova, P.; Zhu, R.; Elkahloun, A.G.; Kourlas, P.J.; Merino, M.; et al. Germ-Line PHD1 and PHD2 Mutations Detected in Patients with Pheochromocytoma/Paraganglioma-Polycythemia. J. Mol. Med. 2015, 93, 93-104. [CrossRef]

30. López-Jiménez, E.; Gómez-López, G.; Leandro-García, L.J.; Muñoz, I.; Schiavi, F.; Montero-Conde, C.; de Cubas, A.A.; Ramires, R.; Landa, I.; Leskelä, S.; et al. Research Resource: Transcriptional Profiling Reveals Different Pseudohypoxic Signatures in SDHB and VHL-Related Pheochromocytomas. Mol. Endocrinol. 2010, 24, 2382-2391. [CrossRef]

31. Tömböl, Z.; Szabó, P.M.; Molnár, V.; Wiener, Z.; Tölgyesi, G.; Horányi, J.; Riesz, P.; Reismann, P.; Patócs, A.; Likó, I.; et al. Integrative Molecular Bioinformatics Study of Human Adrenocortical Tumors: MicroRNA, Tissue-Specific Target Prediction, and Pathway Analysis. Endocr. Relat. Cancer 2009, 16, 895-906. [CrossRef] [PubMed]

32. Soon, P.S.H.; Gill, A.J.; Benn, D.E.; Clarkson, A.; Robinson, B.G.; McDonald, K.L.; Sidhu, S.B. Microarray Gene Expression and Immunohistochemistry Analyses of Adrenocortical Tumors Identify IGF2 and Ki-67 as Useful in Differentiating Carcinomas from Adenomas. Endocr. Relat. Cancer 2009, 16, 573-583. [CrossRef]

33. Demeure, M.J.; Coan, K.E.; Grant, C.S.; Komorowski, R.A.; Stephan, E.; Sinari, S.; Mount, D.; Bussey, K.J. PTTG1 OverExpression in Adrenocortical Cancer Is Associated with Poor Survival and Represents a Potential Therapeutic Target. Surgery 2013, 154, 1405-1416. [CrossRef] [PubMed]

34. Legendre, C.R.; Demeure, M.J.; Whitsett, T.G.; Gooden, G.C.; Bussey, K.J.; Jung, S.; Waibhav, T.; Kim, S.; Salhia, B. Pathway Implications of Aberrant Global Methylation in Adrenocortical Cancer. PLoS ONE 2016, 11, e0150629. [CrossRef]

35. Heaton, J.H.; Wood, M.A.; Kim, A.C.; Lima, L.O.; Barlaskar, F.M.; Almeida, M.Q.; Fragoso, M.C.B.V.; Kuick, R.; Lerario, A.M.; Simon, D.P.; et al. Progression to Adrenocortical Tumorigenesis in Mice and Humans through Insulin-Like Growth Factor 2 and $\beta$-Catenin. Am. J. Pathol. 2012, 181, 1017-1033. [CrossRef] [PubMed]

36. Barrett, T.; Wilhite, S.E.; Ledoux, P.; Evangelista, C.; Kim, I.F.; Tomashevsky, M.; Marshall, K.A.; Phillippy, K.H.; Sherman, P.M.; Holko, M.; et al. NCBI GEO: Archive for Functional Genomics Data Sets-Update. Nucleic Acids Res. 2013, 41, 991-995. [CrossRef]

37. Albrecht, H.; Kübler, E. Systematic Meta-Analysis Identifies Co-Expressed Kinases and GPCRs in Ovarian Cancer Tissues Revealing a Potential for Targeted Kinase Inhibitor Delivery. Pharmaceutics 2019, 11, 454. [CrossRef]

38. Heberle, H.; Meirelles, G.V.; da Silva, F.R.; Telles, G.P.; Minghim, R. InteractiVenn: A Web-Based Tool for the Analysis of Sets through Venn Diagrams. BMC Bioinform. 2015, 16, 169. [CrossRef]

39. Wishart, D.S.; Knox, C.; Guo, A.C.; Cheng, D.; Shrivastava, S.; Tzur, D.; Gautam, B.; Hassanali, M. DrugBank: A Knowledgebase for Drugs, Drug Actions and Drug Targets. Nucleic Acids Res. 2008, 36, 901-906. [CrossRef]

40. Gaulton, A.; Hersey, A.; Nowotka, M.; Bento, A.P.; Chambers, J.; Mendez, D.; Mutowo, P.; Atkinson, F.; Bellis, L.J.; Cibrián-Uhalte, E.; et al. The ChEMBL Database in 2017. Nucleic Acids Res. 2017, 45, D945-D954. [CrossRef]

41. Klingler, M.; Hörmann, A.A.; Guggenberg, E.V. Cholecystokinin-2 Receptor Targeting with Radiolabeled Peptides: Current Status and Future Directions. Curr. Med. Chem. 2020, 27, 7112-7132. [CrossRef] [PubMed]

42. Roy, J.; Putt, K.S.; Coppola, D.; Leon, M.E.; Khalil, F.K.; Centeno, B.A.; Clark, N.; Stark, V.E.; Morse, D.L.; Low, P.S. Assessment of Cholecystokinin 2 Receptor (CCK2R) in Neoplastic Tissue. Oncotarget 2016, 7, 14605-14615. [CrossRef] [PubMed]

43. Dicitore, A.; Cantone, M.C.; Gaudenzi, G.; Saronni, D.; Carra, S.; Borghi, M.O.; Albertelli, M.; Ferone, D.; Hofland, L.J.; Persani, L.; et al. Efficacy of a Novel Second-Generation Somatostatin-Dopamine Chimera (TBR-065) in Human Medullary Thyroid Cancer: A Preclinical Study. NEN 2021, 111, 937-950. [CrossRef] [PubMed]

44. Zink, A.; Scherübl, H.; Höflich, M.; Hescheler, J.; Raue, F. Adenosine A1-Receptors Inhibit CAMP and Ca2+ Mediated Calcitonin Secretion in C-Cells. Horm. Metab. Res. 1995, 27, 408-414. [CrossRef]

45. Richter, G.H.S.; Fasan, A.; Hauer, K.; Grunewald, T.G.P.; Berns, C.; Rössler, S.; Naumann, I.; Staege, M.S.; Fulda, S.; Esposito, I.; et al. G-Protein Coupled Receptor 64 Promotes Invasiveness and Metastasis in Ewing Sarcomas through PGF and MMP1. J. Pathol. 2013, 230, 70-81. [CrossRef] 
46. Peeters, M.C.; Fokkelman, M.; Boogaard, B.; Egerod, K.L.; van de Water, B.; IJzerman, A.P.; Schwartz, T.W. The Adhesion G Protein-Coupled Receptor G2 (ADGRG2/GPR64) Constitutively Activates SRE and NFKB and Is Involved in Cell Adhesion and Migration. Cell. Signal. 2015, 27, 2579-2588. [CrossRef]

47. Jiang, X.; Xu, X.; Wu, M.; Guan, Z.; Su, X.; Chen, S.; Wang, H.; Teng, L. GPRC5A: An Emerging Biomarker in Human Cancer. Biomed Res. Int. 2018, 2018, 1823726. [CrossRef]

48. Ulivieri, A.; Lavra, L.; Dominici, R.; Giacomelli, L.; Brunetti, E.; Sciacca, L.; Trovato, M.; Barresi, G.; Foukakis, T.; Jia-Jing, L.; et al. Frizzled-1 Is down-Regulated in Follicular Thyroid Tumours and Modulates Growth and Invasiveness. J. Pathol. 2008, $215,87-96$. [CrossRef]

49. Sheils, O.M.; Sweeney, E.C. TSH Receptor Status of Thyroid Neoplasms-TaqMan RT-PCR Analysis of Archival Material. J. Pathol. 1999, 188, 87-92. [CrossRef]

50. Elston, M.S.; Gill, A.J.; Conaglen, J.V.; Clarkson, A.; Shaw, J.M.; Law, A.J.J.; Cook, R.J.; Little, N.S.; Clifton-Bligh, R.J.; Robinson, B.G.; et al. Wnt Pathway Inhibitors Are Strongly Down-Regulated in Pituitary Tumors. Endocrinology 2008, 149, 1235-1242. [CrossRef]

51. Ren, J.; Jian, F.; Jiang, H.; Sun, Y.; Pan, S.; Gu, C.; Chen, X.; Wang, W.; Ning, G.; Bian, L.; et al. Decreased Expression of SFRP2 Promotes Development of the Pituitary Corticotroph Adenoma by Upregulating Wnt Signaling. Int. J. Oncol. 2018, 52, $1934-1946$. [CrossRef] [PubMed]

52. Wu, Y.; Bai, J.; Li, Z.; Wang, F.; Cao, L.; Liu, C.; Yu, S.; Yu, G.; Zhang, Y. Low Expression of Secreted Frizzled-Related Protein 4 in Aggressive Pituitary Adenoma. Pituitary 2015, 18, 335-342. [CrossRef] [PubMed]

53. Nishikawa, T.; Tsuno, N.H.; Shuno, Y.; Sasaki, K.; Hongo, K.; Okaji, Y.; Sunami, E.; Kitayama, J.; Takahashi, K.; Nagawa, H. Antiangiogenic Effect of a Selective 5-HT4 Receptor Agonist. J. Surg. Res. 2010, 159, 696-704. [CrossRef]

54. Zhang, L.; Song, Q.; Zhang, X.; Li, L.; Xu, X.; Xu, X.; Li, X.; Wang, Z.; Lin, Y.; Li, X.; et al. Zelnorm, an Agonist of 5Hydroxytryptamine 4-Receptor, Acts as a Potential Antitumor Drug by Targeting JAK/STAT3 Signaling. Investig. New Drugs 2020, 38, 311-320. [CrossRef] [PubMed]

55. Pawlikowski, M.; Winczyk, K.; Sledź, B. Immunohistochemical Detection of Angiotensin Receptors AT1 and AT2 in Adrenal Tumors. Folia Histochem. Et Cytobiol. 2008, 46, 51-55. [CrossRef]

56. Wolf, G.; Harendza, S.; Schroeder, R.; Wenzel, U.; Zahner, G.; Butzmann, U.; Freeman, R.S.; Stahl, R.A.K. Angiotensin II's Antiproliferative Effects Mediated Through AT2-Receptors Depend On Down-Regulation of SM-20. Lab. Investig. 2002, 82, $1305-1317$. [CrossRef] [PubMed]

57. Zhao, N.; Peacock, S.O.; Lo, C.H.; Heidman, L.M.; Rice, M.A.; Fahrenholtz, C.D.; Greene, A.M.; Magani, F.; Copello, V.A.; Martinez, M.J.; et al. Arginine Vasopressin Receptor 1a Is a Therapeutic Target for Castration-Resistant Prostate Cancer. Sci. Transl. Med. 2019, 11, eaaw4636. [CrossRef]

58. Mazzocchi, G.; Aragona, F.; Malendowicz, L.K.; Nussdorfer, G.G. PTH and PTH-Related Peptide Enhance Steroid Secretion from Human Adrenocortical Cells. Am. J. Physiol. Endocrinol. Metab. 2001, 280, 209-213. [CrossRef]

59. Gao, X.; Yamazaki, Y.; Tezuka, Y.; Onodera, Y.; Ogata, H.; Omata, K.; Morimoto, R.; Nakamura, Y.; Satoh, F.; Sasano, H. The Crosstalk between Aldosterone and Calcium Metabolism in Primary Aldosteronism: A Possible Calcium Metabolism-Associated Aberrant "Neoplastic" Steroidogenesis in Adrenals. J. Steroid Biochem. Mol. Biol. 2019, 193, 105434. [CrossRef]

60. Rizk-Rabin, M.; Assie, G.; Rene-Corail, F.; Perlemoine, K.; Hamzaoui, H.; Tissier, F.; Lieberherr, M.; Bertagna, X.; Bertherat, J.; Bouizar, Z. Differential Expression of Parathyroid Hormone-Related Protein in Adrenocortical Tumors: Autocrine/Paracrine Effects on the Growth and Signaling Pathways in H295R Cells. Cancer Epidemiol. Biomark. Prev. 2008, 17, 2275-2285. [CrossRef]

61. Song, G.J.; Fiaschi-Taesch, N.; Bisello, A. Endogenous Parathyroid Hormone-Related Protein Regulates the Expression of PTH Type 1 Receptor and Proliferation of Vascular Smooth Muscle Cells. Mol. Endocrinol. 2009, 23, 1681-1690. [CrossRef] [PubMed]

62. Ho, P.W.M.; Goradia, A.; Russell, M.R.; Chalk, A.M.; Milley, K.M.; Baker, E.K.; Danks, J.A.; Slavin, J.L.; Walia, M.; Crimeen-Irwin, B.; et al. Knockdown of PTHR1 in Osteosarcoma Cells Decreases Invasion and Growth and Increases Tumor Differentiation in Vivo. Oncogene 2015, 34, 2922-2933. [CrossRef] [PubMed]

63. Jonklaas, J.; Sarlis, N.J.; Litofsky, D.; Ain, K.B.; Bigos, S.T.; Brierley, J.D.; Cooper, D.S.; Haugen, B.R.; Ladenson, P.W.; Magner, J.; et al. Outcomes of Patients with Differentiated Thyroid Carcinoma Following Initial Therapy. Thyroid 2006, 16, 1229-1242. [CrossRef] [PubMed]

64. Marchalant, Y.; Brownjohn, P.W.; Bonnet, A.; Kleffmann, T.; Ashton, J.C. Validating Antibodies to the Cannabinoid CB2 Receptor. J. Histochem. Cytochem. 2014, 62, 395-404. [CrossRef]

65. Kaiser, F.; Morawski, M.; Krohn, K.; Rayes, N.; Hsiao, C.-C.; Quaas, M.; Aust, G. Adhesion GPCR GPR56 Expression Profiling in Human Tissues. Cells 2021, 10, 3557. [CrossRef]

66. Koussounadis, A.; Langdon, S.P.; Um, I.H.; Harrison, D.J.; Smith, V.A. Relationship between Differentially Expressed MRNA and MRNA-Protein Correlations in a Xenograft Model System. Sci. Rep. 2015, 5, 10775. [CrossRef] 